\title{
PREDIKTOR SIKAP STIGMA DAN DISKRIMINASI TERHADAP ORANG DENGAN HIV DANAIDS(ODHA) DI KABUPATEN JEMBER
}

\author{
Predictor of Stigma and Discrimination Attitude to Person Living with HIV and AIDS \\ (PLHIV) In Jember District
}

\author{
Ni'malBaroya \\ Bagian Epidemiologi dan Biostatistika Kependudukan, \\ Fakultas Kesehatan Masyarakat Universitas Jember; \\ Jl. Kalimantan No.37 KampusTegalBotoJember; \\ email: nbaroya@unej.ac.id
}

\begin{abstract}
Globally, the HIV and AIDS epidemic shows stable conditions, but statistically there is still an increase in new infections in some areas including Jember District. The main barriers to HIV prevention are stigma and discrimination against people living with HIV. This study aims to analyze the predictors of stigma and discrimination attitude toward PLHIV in Jember District. This was an observational study used cross sectional design. Research subjects were people aged 15-24 years amounted to 247 respondents. Determination of the sample using a multistage sampling technique, ie the determination of simple random cluster of villages and then determine the respondents of each cluster randomly systematic. Data were collected using structured interview technique with questionnaire then analyzed using chi-square test and logistic regression with 5\% significance level. The results showed the majority of respondents (81.4\%) stated not willing to buy food if the seller knew HIV +. Fifty percent more they disagree if female teachers who are HIV + keep teaching. Similarly, children with HIV + cannot be admitted to school with HIV negative children. The distribution of stigma and discrimination attitudes toward people living with HIV significantly differed by age, sex, education level, marital status and occupational status. The level of knowledge and residence does not differ significantly. A significant factor to be a predictor of stigma and discrimination against people living with HIV is age and gender. Younger age (15-19 years) and women have a greater likelihood of being stigmatized and discriminating against people living with HIV. Dissemination of information about HIV and AIDS in adolescents aged 15-19 years is still needed to increase knowledge and accelerate the acceptance of PLHIV so that stigma and discrimination attitude toward PLWHA can be reduced.
\end{abstract}

Keywords: attitude, stigma, discrimination people suffering with HIV and AIDS.

\begin{abstract}
Abstrak
Secara global, epidemi HIV dan AIDS sudah stabil, namun masih terdapat peningkatan infeksi baru di beberapa wilayah termasuk Kabupaten Jember. Hambatan utama dalam pencegahan HIV adalah stigma dan diskriminasi terhadap ODHA. Penelitian ini bertujuan menganalisis prediktor sikap stigma dan diskriminasi terhadap ODHA di Kabupaten Jember. Penelitian yang bersifat observasional ini menggunakan disain cross sectional. Ni'mal Baroya adalah Bagian Epidemiologi dan Biostatistika Kependudukan Fakultas Kesehatan Masyarakat Universitas Jember
\end{abstract}


Subjek penelitian adalah masyarakat berusia 15-24 tahun berjumlah 247 responden. Penentuan sampel menggunakan teknik sampling bertahap, yaitu penentuan klaster desa secara acak sederhana kemudian menentukan responden tiap klaster secara acak sistematik. Data dikumpulkan menggunakan teknik wawancara terstruktur dan self report dengan kuesionerkemudiandianalisismenggunakanuji chi-square danregresi logistic dengantingkatsignifikansi 5\%. Hasil penelitian menunjukkan mayoritas responden(81,4\%) menyatakan tidak bersedia membeli makanan jika mengetahui penjualnya $\mathrm{HIV}^{+}$. Lima puluh persen lebih mereka tidak setuju jika guru perempuan yang $\mathrm{HIV}^{+}$tetap mengajar. Demikian juga terhadap anak yang HIV+ belum bisa diterima sekolah bersama anak yang HIV negatif. Distribusi sikap stigma dan diskriminasi terhadap ODHA secara signifikan berbeda menurut usia, jenis kelamin, tingkat pendidikan, status pernikahan dan status pekerjaan. Adapun tingkat pengetahuan dantempat tinggal tidak berbeda secara signifikan. Faktor yang signifikan menjadi prediktor sikap stigma dan diskriminasi terhadap ODHA adalah usia dan jenis kelamin. Usia lebih muda (15-19 tahun) dan perempuan mempunyai kemungkinan lebih besar bersikap menstigma dan mendiskriminasi terhadap ODHA. Diseminasi informasi tentang HIV dan AIDSpadaremajausia 15-19 tahun tetap diperlukan untukmeningkatkan pengetahuan dan mempercepat penerimaan terhadap ODHA sehingga sikap stigma dan diskriminasi terhadap ODHA bisa berkurang.

Kata Kunci: sikap, stigma, diskriminasi, ODHA.

\section{PENDAHULUAN}

Secara global, HIV dan AIDS masih menjadi masalah kesehatan masyarakat yang serius. Meskipun saat ini epidemi HIV dan AIDS secara global menunjukkan kondisi stabil, namun secara statistik masih dilaporkan terdapat peningkatan jumlah infeksi baru di beberapa negara ${ }^{1}$ termasuk Indonesia. Kabupaten Jember merupakan salah satu kabupaten yang harus bekerja keras dalam melawan laju epidemi HIV dan AIDS. Sejak tahun 2009, kasus HIV dan AIDS di Kabupaten Jember terus meningkat setiap tahun. Secara kumulatif, kasus HIV dan AIDS di Kabupaten Jember sampai dengan April 2017 mencapai 3.065 kasus $^{2}$.

Orang Dengan HIV dan AIDS (ODHA) tidak hanya berhadapan dengan masalah kesehatan namun juga menghadapi masalah sosial yang berhubungan dengan penyakitnya. Salah satu hambatan yang dialami orang berisiko atau yang terinfeksi HIV dan AIDS adalah stigma ${ }^{3}$. Stigma meningkatkan ketertutupan dan penolakan sehingga berakibat sebagai katalisator penularan ${ }^{4}$. Reaksi yang diterima ODHA terhadap status infeksinya dari orang lain bermacammacam. Beberapa ODHA mendapat dukungan sehingga secara positif mempengaruhi hidupnya. Terdapat juga ODHA yang mendapat stigma negatif sehingga mempengaruhi ODHA dalam pencarian pelayanan test HIV, pencarian pelayanan perawatan kesehatan setelah terdiagnosis, kualitas perawatan yang diberikan kepada pasien HIV positif dan akhirnya muncul persepsi dan perawatan negatif yang diterima ODHA dari masyarakat, keluarga bahkan pasangannya $^{5}$. Hal ini menjadikan 
terjadinya pengucilan terhadap ODHA dari komunitasnya dan pada akhirnya berdampak pada keseluruhan kualitas hidupnya ${ }^{3,4}$.

Stigma terhadap HIV dan AIDS menghasilkan sikap diskriminasi dan akhirnya mengakibatkan penyebaran HIV dan AIDS semakin meluas ${ }^{6}$. Ketakutan teridentifikasi sebagai ODHA menghambat seseorang mengambil pelajaran dari statusnya, mengubah perilaku yang tidak aman dan mendapat perawatan sebagai ODHA ${ }^{7}$. Sebuah penelitian di Botswana dan Zambia menemukan bahwa stigma terhadap ODHA mencegah seseorang berpartisipasi dalam program Voluntary Couselling and Testing (VCT) dan program pencegahan penularan dari ibu ke anak ${ }^{8}$. Stigma dan diskriminasi juga secara intensif menyakiti ODHA dan keluarganya ${ }^{7}$.

$$
\text { Orang }
$$

DenganHIV

danAIDS(ODHA)terstigma karena beberapa alasan, yaitu 1) penyakit yang diderita dianggap berhubungan dengan perilaku menyimpang, 2) dipandang sebagai penyakit karena perilakunya sendiri sehingga menjadi tanggung jawab individu, 3) menodai agama dan kepercayaannya karena sudah berperilaku tidak bermoral, 4) dianggap menularkan dan mengancam masyarakat sekitarnya, 5) berhubungan dengan kematian yang tidak menyenangkan dan tidak wajar, dan 6) tidak diterima dengan baik oleh masyarakat sekitarnya dan menerima pandangan negatif dari petugas kesehatan ${ }^{7}$. Masih sedikit ditemukan penelitian tentang stigma dan diskrimasi terhadap orang dengan HIV dan AIDS di Indonesia apalagi di Jember. Diskriminasi terhadap ODHA atau orang yang diduga terinfeksi HIV tidak hanya merupakan sikap yang salah dan melanggar hak asasi manusia, namun juga menjadikan ketidakefektifan dalam pengukuran status kesehatan masyarakat di Indonesia pada umumnya, dan Kabupaten Jember pada khususnya. Jika hal ini tidak segera mendapat perhatian, target SDGs ke-6 akan sulit tercapai.

Upaya pengurangan stigma dan diskriminasi terhadap ODHA menjadi salah satu strategi dalam respon global dan nasional terhadap epidemi HIV dan AIDS. Oleh karena itu, diperlukan sebuah penelitian yang mampu menjadi basis bukti untuk merumuskan program pengurangan stigma dan diskriminasi terhadap ODHA. Penelitian ini berusaha mengungkap tentang faktor yang mempengaruhi sikap stigma dan diskriminasi terhadap ODHA di Kabupaten Jember dengan pendekatan modifikasi kerangka konsep yang dikembangkan di Bostwana dan faktor yang terkait dengan stigma yang terdiri atas konstruksi sosial, stereotype, kepercayaan tertentu, akses dan peran program anti retroviral therapy (ART), agama dan gender ${ }^{7,8}$. Variabel yang merefleksikan pengetahuan tentang penularan HIV dan AIDS serta karaktersitik sosial dan demografi individu digunakan sebagai variabel prediktor sikap stigma dan diskriminasi terhadap ODHA.

Tujuan utama penelitian ini adalah mendapatkan gambaran prevalensi dan menganalisis faktor yang mampu menjadi prediktor sikap stigma dan diskriminasi terhadap ODHA di Kabupaten Jember. Adapun secara khusus, penelitian ini bertujuan sebagai berikut (1) mengidentifikasi karakteristik sosiodemografi, pengetahuan dan sikap stigma dan diskriminasi terhadap ODHA di Kabupaten Jember, (2) menganalisis perbedaan sikap stigma dan diskriminasi terhadap ODHA berdasarkan karakteristik sosiodemografi dan 
pengetahuan tentang HIV dan AIDS di Kabupaten Jember dan (3) menganalisis prediktor sikap stigma dan diskriminasi terhadap ODHA berdasarkan karakteristik sosiodemografi dan pengetahuan tentang HIV dan AIDS di Kabupaten Jember.

\section{METODE PENELITIAN}

Penelitian ini bersifat analitik, observaional dan menggunakan pendekatan cross sectional karena variabel bebas dan variabel terikat diamati pada saat bersamaan. Subjek penelitian ini adalah pendudukKabupatenJemberyang berusia 15-24. Penentuanbesar sampel penelitianmengikutimetode rapid survey, yaitu membutuhkan 30 klaster desa dan setiap klaster diambil sebanyak 7-10 rumah tangga. Dengan demikian besar sampel penelitian ini berjumlah 247 responden.Teknik sampling dalampenelitianinimenerapkan rancangan sampel 2 tahap, yaitu pemilihan klaster secara probability proportionate size dan pemilihan sampel rumah tangga secara simple random atau dengan sistem rumah terdekat.

Variabel penelitian ini terdiri atas variabel bebas (prediktor) yang meliputikarakteristik demografi (usia, jenis kelamin, status pernikahan), karakteristik sosial (tingkat pendidikan, status pekerjaan dan tempat tinggal) serta tingkat pengetahuan HIV dan AIDS. Adapun variabel terikat atau variabel respon dalam penelitian ini adalah sikap stigma dan diskriminasi terhadap ODHA. Penelitian ini mengumpulkan data primer dan sekunder. Data primer diperoleh melalui wawancara langsung ke seluruh responden dengan menggunakan kuesioner. Sedangkan data sekunder diperoleh dengan cara mencatat dokumentasi data ODHA yang dikumpulkan oleh KPA Kabupaten Jember. Data yang telah dikumpulkan diolah menggunakan software pengolah data kemudian data dianalisis secara univariabel, bivariabel dan multivariabel. Analisis bivariabel menggunakan uji statistik chi-square sedangkan analisis multivariabel untukmendapatkan predictor sikap stigma dandiskriminasiterhadap ODHA menggunakan uji regresi logistic dengan $\alpha=5 \%{ }^{9}$.

\section{HASIL DAN PEMBAHASAN}

Penelitian yang menggunakan subjek populasi umum berusia 15-24 tahun ini memberikanhasil bahwa tingkat penerimaan terhadap ODHA di Kabupaten Jember masih memprihatinkan. Mayoritas $(81,4 \%)$ responden masih menyatakan tidak bersedia membeli makanan jika mengetahui penjualnya $\mathrm{HIV}^{+}$.Sebagianbesarresponden $\quad$ (75\%) masihmempunyaikekhawatiranterinfeksi HIV hanyadengancarakontakludah ODHA. Lima puluh persen lebih mareka tidak setuju jika guru perempuan yang $\mathrm{HIV}^{+}$tetap mengajar meskipun tidak sakit. Demikian juga terhadap anak yang $\mathrm{HIV}^{+}$belum bisa diterima sekolah bersama anak yang HIV- Kondisi ini berbeda dengan di Kenya yang tingkat penerimaan masyarakat umum terhadap ODHA sudah cukup tinggi $(60 \%$ persen bisa menerima guru perempuan yang HIV $^{+}$). Secara detail gambaransikap stigma dandiskriminasiterhadap ODHA biasdilihatpadaTabel 1. 
Tabel1. DeskripsiSikap Stigma danDiskriminasiTerhadap Orang DenganHIV dan AIDS (ODHA)di KabupatenJember

\begin{tabular}{|c|c|c|c|c|c|}
\hline \multirow{2}{*}{\multicolumn{2}{|c|}{ Pernyataan }} & \multicolumn{2}{|r|}{ tuju } & \multicolumn{2}{|c|}{$\begin{array}{l}\text { Tidak } \\
\text { Setuju }\end{array}$} \\
\hline & & $\mathbf{n}$ & 6 & $\mathrm{n}$ & $\%$ \\
\hline \multicolumn{2}{|c|}{$\begin{array}{l}\text { Ada rasa khawatir terinfeksi HIV jika kontak dengan } \\
\text { ludah orang positif HIV }\end{array}$} & 185 & 74,9 & 62 & 25,1 \\
\hline \multicolumn{2}{|c|}{$\begin{array}{l}\text { Merasamalu jika mempunyai anggota keluarga yang } \\
\text { terinfeksi HIV }\end{array}$} & 119 & 48,2 & 128 & 51,8 \\
\hline \multicolumn{2}{|c|}{$\begin{array}{l}\text { Raguuntuk melakukan test HIV karena takut terhadap } \\
\text { reaksi orang sekitar jika hasil test menyatakan positif } \\
\text { HIV }\end{array}$} & 95 & 38,5 & 152 & 61,5 \\
\hline \multicolumn{2}{|c|}{$\begin{array}{l}\text { Orang-orang membicarakan hal yang buruk tentang } \\
\text { ODHA dan OHIDA }\end{array}$} & 86 & 34,8 & 161 & 65,2 \\
\hline \multicolumn{2}{|c|}{$\begin{array}{l}\text { ODHA dan OHIDA kehilangan kehormatan atau } \\
\text { kedudukan }\end{array}$} & 118 & 47,8 & 129 & 52,2 \\
\hline \multicolumn{2}{|c|}{$\begin{array}{l}\text { Tetap membeli makanan meskipun tahu penjualnya } \\
\text { positif HIV }\end{array}$} & 46 & 18,6 & 201 & 1,4 \\
\hline \multicolumn{2}{|c|}{$\begin{array}{l}\text { Anak yang positif HIV tetap bisa sekolah bersama } \\
\text { dengan anak-anak negatif HIV }\end{array}$} & 119 & 48,2 & 128 & 51,8 \\
\hline \multicolumn{2}{|c|}{$\begin{array}{l}\text { Guru perempuan yang positif HIV tapi tidak sakit harus } \\
\text { tetap diperkenankan mengajar di sekolah seperti biasa }\end{array}$} & 107 & 43,3 & 140 & 56,7 \\
\hline \multicolumn{2}{|c|}{ Bersediamerawat anggota keluarga yang positif HIV } & & 74,1 & 64 & 5,9 \\
\hline $\begin{array}{l}\text { Perbedaan tingkat penerimaan } \\
\text { sebagai manifestasi sikap stigma } \\
\text { terhadap ODHA antara masyarakat } \\
\text { Kenya dan masyarakat Jember di } \\
\text { Indonesia merupakan konsekuensi dari } \\
\text { perbedaan situasi epidemi HIV di } \\
\text { masing-masing wilayah. Tingginya } \\
\text { tingkat penerimaan terhadap ODHA di } \\
\text { Kenya bisa dijelaskan berdasarkan fakta } \\
\text { bahwa proporsi masyarakat umum yang } \\
\text { mengetahui orang berstatus ODHA atau } \\
\text { meninggal karena AIDS sudah tinggi. } \\
\text { Dengan kata lain, infeksi HIV sudah tidak } \\
\text { dipandang sebagai peristiwa langka atau } \\
\text { menyimpang dari pengalaman sehari- } \\
\text { hari. Hal inilah yang mengurangi sikap } \\
\text { stigma masyarakat terhadap ODHA }{ }^{10} \text {. } \\
\text { Sementara, epidemi HIV dan AIDS di } \\
\text { Indonesia pada umumnya (kecuali } \\
\text { Papua) dan Jember khususnya masih } \\
\text { pada tahap terkonsentrasi. Sehingga } \\
\text { sebagian masyarakat umum }\end{array}$ & \multicolumn{5}{|c|}{ 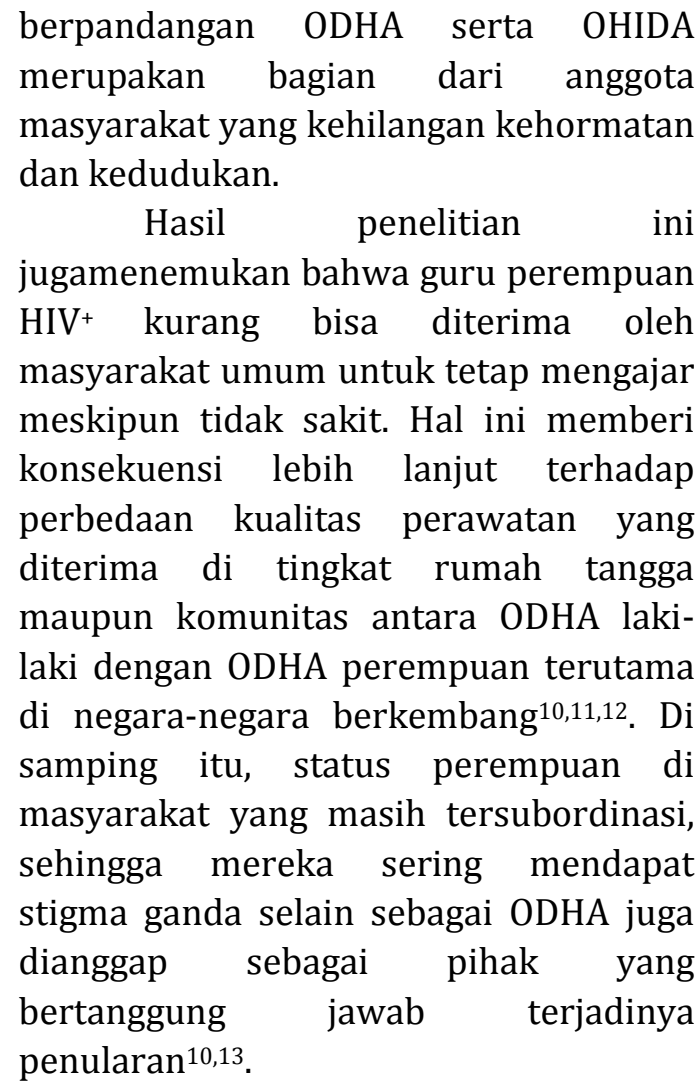 } \\
\hline
\end{tabular}


Namunhasilpenelitianinijugamemberika ninformasi yang mampumembangkitkan rasa optismisdalammenjalankan program penanggulangan HIV di KabupatenJemberyaituterdapat $\quad 74,1 \%$ responden yang menyatakanbersediamerawatanggotakel uarga yang positif HIV meskipunmasihterdapat $\quad 48,2 \%$ responden yang merasamalujikamempunyaianggotakelua rga yang terinfeksi HIV. Di sampingitukeraguanuntuk melakukan test HIV karena takut terhadap reaksi orang sekitar jika hasil test menyatakan positif HIVsudahtidakterlalubesar $(38,5 \%)$.

Berdasarkanresponterhadappern yataansikap stigma dandiskriminasiterhadap ODHA, kemudianjumlahskorsikapdikelompokka nmenjadi 2 kategoriyaitusikap stigma jikajumlahskorsikap $\leq 4$ dansikaptidak stigma jikajumlahskorsikap> 4 . Hasilanalisismenunjukkanlebihbanyakre sponden yang mempunyaisikap stigma daripada yang tidak, masing-masing $53 \%$ dan 47\%.Secara detail, sikap stigma dandiskriminasiterhadap ODHA tersajidalamTabel

2.

Tabel2. Sikap Stigma danDiskriminasiterhadap ODHA

\begin{tabular}{lll}
\hline Sikap Stigma danDiskriminasi ODHA & n & $\mathbf{\%}$ \\
\hline Ya & 131 & 53 \\
Tidak & 116 & 47 \\
\hline Total & 247 & 100 \\
\hline
\end{tabular}

\section{kanujichi}

Hasilanalisisbivariabelmengguna

squaredananalisisbesarrisikomenggunak anpenghitunganodds ratiodalam penelitian inimenunjukkan bahwa sikap stigma dan diskriminasi terhadap ODHA secara signifikan berhubungan dengan karakteristik sosiodemografi. Usia, jenis kelamin, tingkat pendidikan, status pernikahan dan status pekerjaan secara signifikan berhubungan dengan sikap stigma dan diskriminasi terhadap ODHA. Usia lebih muda (15-19 tahun) mempunyai kemungkinan bersikap menstigma dan mendiskriminasi ODHA 2 kali lebih besar daripada yang berusia lebih tua (20-24 tahun). Hal ini dibuktikan dengan nilai $\mathrm{OR}=1,943 ; 95 \%$ $\mathrm{CI}=2,10-7,96$. Perempuan, lebih mungkin bersikap menstigma dan mendiskriminasi ODHA 2 kali lebih besar daripada laki-laki $\quad(\mathrm{OR}=1,918 ; \quad 95 \%$ $\mathrm{CI}=1,15-3,19)$. Demikian juga status pernikahan dan status pekerjaan.
Berstatus menikah dan tidak bekerja lebih mungkin mempunyai sikap stigma dan diskriminasi terhadap ODHA 2 kali lebih besar dibandingkan dengan yang belum menikah dan bekerja (masingmasing OR; 95\% CI $=2,00 ; 1,02-3,94$ \& $2,05 ; 1,15-3,04)$.

Sikap stigma dan diskriminasi terhadap ODHA juga berbeda menurut tingkat pendidikan. Semakin rendah tingkat pendidikan, kemungkinan bersikap menstigma dan mendiskriminasi ODHA semakin besar. Berpendidikan Sekolah Dasar (SD), 2,43 kali lebih besar mempunyai sikap stigma dan diskriminasi terhadap ODHA dibandingkan dengan mereka yang berpendidikan SLTA atau PT (95\% $\mathrm{CI}=1,00-5,82)$. Sementara itu, berpendidikan SLTP mempunyai kemungkinan 1,83 kali lebih besar bersikap menstigma dan mendiskriminasi ODHA dibandingkan dengan yang berpendidikan SLTA atau 
PT (95\% CI=1,06-3,15). Tempat tinggal dengan sikap stigma dan diskriminasi dantingkatpengetahuantentang HIV dan terhadap

ODHA. AIDS tidak signifikan berhubungan

Tabel 3. Persentase, Odds-ratio dan 95\% CI Sikap Stigma dan Diskriminasi TerhadapODHA

\begin{tabular}{|c|c|c|c|c|c|c|c|c|}
\hline \multirow[t]{3}{*}{ Variabel } & \multicolumn{4}{|c|}{$\begin{array}{c}\text { Sikap Stigma dan } \\
\text { Diskriminasi Terhadap } \\
\text { ODHA }\end{array}$} & \multirow[t]{3}{*}{$X^{2}$} & \multirow[t]{3}{*}{ P-value } & \multirow[t]{3}{*}{ OR } & \multirow[t]{3}{*}{$95 \%$ CI } \\
\hline & \multicolumn{2}{|c|}{ Ya } & \multicolumn{2}{|c|}{ Tidak } & & & & \\
\hline & $\mathrm{n}$ & $\%$ & $\mathbf{n}$ & $\%$ & & & & \\
\hline \multicolumn{9}{|l|}{ Usia } \\
\hline $15-19$ thn & 97 & 39,3 & 69 & 27,9 & \multirow{2}{*}{5,278} & \multirow{2}{*}{$0,022 *$} & 1,943 & \multirow[t]{2}{*}{$(2,10-7,96)^{*}$} \\
\hline $20-24$ thn & 34 & 13,8 & 47 & 19,0 & & & 1 & \\
\hline \multicolumn{9}{|l|}{ Jenis } \\
\hline \multicolumn{9}{|l|}{ Kelamin } \\
\hline Perempuan & 83 & 33,6 & 56 & 22,7 & \multirow{2}{*}{5,092} & \multirow{2}{*}{$\mathbf{0 , 0 2 4} *$} & 1,918 & \multirow[t]{2}{*}{$(1,15-3,19) *$} \\
\hline Laki-laki & 48 & 19,4 & 60 & 24,3 & & & 1 & \\
\hline \multicolumn{9}{|l|}{ Status } \\
\hline \multicolumn{9}{|l|}{ Pernikahan } \\
\hline Menikah & 30 & 12,1 & 15 & 6,1 & & & 2,00 & $(1,02-3,94)^{*}$ \\
\hline $\begin{array}{l}\text { Belum } \\
\text { menikah }\end{array}$ & 101 & 40,9 & 101 & 40,9 & 3,462 & 0,063 & 1 & \\
\hline \multicolumn{9}{|l|}{ Pendidikan } \\
\hline SD & 18 & 7,3 & 10 & 4,0 & \multirow{3}{*}{6,374} & \multirow{3}{*}{$0,041 *$} & 2,42 & \multirow{3}{*}{$\begin{array}{l}(1,00-5,82)^{*} \\
(1,06-3,15)^{*}\end{array}$} \\
\hline SLTP & 75 & 30,4 & 55 & 22,3 & & & 1,83 & \\
\hline SLTA\&PT & 38 & 15,4 & 51 & 20,6 & & & 1 & \\
\hline \multicolumn{9}{|l|}{ Status } \\
\hline \multicolumn{9}{|l|}{ Pekerjaan } \\
\hline Tidak & 105 & 42,5 & 77 & 31,2 & \multirow{3}{*}{5,330} & \multirow{3}{*}{$0,021^{*}$} & 2,05 & \multirow[t]{3}{*}{$(1,15-3,64)^{*}$} \\
\hline Bekerja & & & & & & & & \\
\hline Bekerja & 26 & 10,5 & 39 & 15,8 & & & 1 & \\
\hline \multicolumn{9}{|l|}{ Tempat } \\
\hline Tinggal & & & & & & & & \\
\hline Perdesaan & 116 & 47,0 & 103 & 41,7 & 0000 & 1000 & 1,03 & $(0,46-2,25)$ \\
\hline Perkotaan & 15 & 6,0 & 13 & 5,3 & 0,000 & 1,000 & 1 & \\
\hline Tingkat & & & & & & & & \\
\hline Pengetahuan & & & & & & & & \\
\hline Kurang & 15 & 6,1 & 11 & 4,5 & & & 1,485 & $(0,63-3,51)$ \\
\hline Sedang & 60 & 24,3 & 44 & 17,8 & 2,388 & 0,303 & 1,485 & $(0,87-2,53)$ \\
\hline Baik & 56 & 22,7 & 61 & 24,7 & & & 1 & \\
\hline
\end{tabular}

Keterangan: * signifikan $\alpha<0,05$

Temuan hasil penelitian ini konsisten dengan penelitian sebelumnya di beberapa wilayah termasuk di Kenya, Amerika Serikat dan China yang menemukan bahwa penerimaan terhadap ODHA secara signifikan berhubungan dengan usia, pendidikan, pengetahuan tentang AIDS, meskipun 

tingkat komunitas ${ }^{10}$. Namun hasil penelitian ini menemukan bahwa tempat tinggal dan tingkat pengetahuan tentang HIV dan AIDS tidak signifikan berhubungan dengan sikap stigma dan diskriminasi terhadap ODHA (masingmasing $p$-value $=1,000$ dan 0,303). Berkaitan dengan temuan tersebut, hasil penelitian ini tidak konsisten dengan penelitian sebelumnya yang menyatakan bahwa pengetahuan yang baik tentang HIV dan AIDS dapat mengurangi sikap tidak toleran terhadap ODHA $^{10,14,15}$. Tempat tinggal tidak menjadi faktor yang signifikan berhubungan dengan sikap stigma dan diskriminasi terhadap ODHA. Hasil penelitian ini tidak sejalan dengan hasil penelitian di Thailand yang menemukan bahwa reaksi terhadap ODHA lebih positif pada masyarakat yang tinggal di pedesaan daripada perkotaan ${ }^{16}$.

Berdasarkanhasilanalisisbivariab elmenggunakanujichi-square, terdapat lima variableyang dapatdilajutkandalamanalisismultivariab lemenggunakanregresi logistic binerkarenamempunyai $\mathrm{p}=$ value $<0,25$. Variabeltersebutadalahusia,

jeniskelamin, pendidikan, status pernikahan, dan status pekerjaan. Denganmenggunakanmetodebackward nilai yang dihasilkansebagaiberikut:

1. NilaiNegelkerke $\mathrm{R}^{2}$ padatableModel Summarymenujukkanbahwadari lima variablebebastersebutmampumenjela skankeragaman total darisikap stigma dandiskriminasiterhadap ODHA sebesar 7,7\% (Step 4).

2. Penilaiankelayakan model regresidalammemprediksidilakukand enganHosmerand Lemeshow Test ${ }^{9}$. Pengujianinidilakukanuntukmengujihi potesis $\mathrm{HO}=$ tidakadaperbedaanantaraklasifikasipr ediksidenganklasifikasi yang diamati; dan $\mathrm{H1}=$ adaperbedaanantaraklasifikasiprediks idenganklasifikasi yang diamati. NilaiHosmer and LemeshowTestpada step 1 - step 4, seluruhnya> 0,05 (step $4=0,472$ ), sehinggaharusmenerima $\mathrm{HO}$.

Dengandemikiandapatdisimpulkanba hwaestimasi model sesuaidengan data aktual yang digunakan.

3. NilaiOverall PercentagepadaClassification

Tablesebesar 59,1\% (step 4). Nilaiinimenunjukkanbahwanilaiketep atanprediksicukupbaikjikadigunakan untukmemprediksisikap stigma dandiskriminasiterhadap ODHA.

Tabel 4. HasilPengujian Model RegresiLogistik

\begin{tabular}{|c|c|}
\hline HasilPengujian & Nilai \\
\hline \multirow[t]{4}{*}{ Model Summary (Negelkerke $R^{2}$ ) } & Step 1=9,4\% \\
\hline & Step $2=9 \%$ \\
\hline & Step $3=8,8 \%$ \\
\hline & Step $4=7,7 \%$ \\
\hline \multirow[t]{4}{*}{ Hosmer and Lemeshow Test } & Step $1=\left(p\right.$-value $\left.=0,795 ; \chi_{2}=3,870\right)$ \\
\hline & Step $2=\left(p\right.$-value $\left.=0,863 ; \chi_{2}=2,546\right)$ \\
\hline & Step $3=\left(p\right.$-value $\left.=0,687 ; x_{2}=2,263\right)$ \\
\hline & Step $4=\left(p\right.$-value $\left.=0,472 ; \chi_{2}=1,504\right)$ \\
\hline \multirow{2}{*}{ Classification Table (Overall percenrage) } & Step $1=61,5 \%$ \\
\hline & Step $2=60,3 \%$ \\
\hline
\end{tabular}




\begin{tabular}{ll}
\hline HasilPengujian & Nilai \\
\hline & Step 3 $=59,1 \%$ \\
Step $4=59,1 \%$ \\
\hline Log likelihood & Step 1 $=323.388$ \\
& Step 2=324.238 \\
Step 3 $=324.571$ \\
Step 4=326.823
\end{tabular}

4. Nilai signifikansi hasil analisis multivariabel pada Table in the equation menunjukkan bahwa prediktor sikap stigma dan diskriminasi terhadap ODHA terdiri atas variabel usia dan status pernikahan (lihat Tabel 5.)

Tabel 5. Model RegresiLogistik

\begin{tabular}{|c|c|c|c|c|c|}
\hline Variabel & & B & P-value & OR & $95 \% \mathrm{CI}$ \\
\hline \multirow{9}{*}{ Step 1} & Usia(1) & 0,707 & 0,058 & 2,028 & $0,977-4,212$ \\
\hline & Jenis kelamin(1) & 0,363 & 0,222 & 1,438 & $0,803-2,575$ \\
\hline & Status & 0,818 & 0,049 & 2,265 & $1,004-5,108$ \\
\hline & Menikah(1) & & & & \\
\hline & Education & & 0,657 & & \\
\hline & Education(1) & 0,444 & 0,360 & 1,559 & $0,602-4,034$ \\
\hline & Education(2) & 0,133 & 0,689 & 1,142 & $0,596-2,189$ \\
\hline & Bekerja(1) & $-0,192$ & 0,600 & 0,826 & $0,404-1,689$ \\
\hline & Constant & $-0,770$ & 0,055 & 0,463 & \\
\hline \multirow{5}{*}{ Step 2} & Kelumur(1) & 0,805 & 0,018 & 2,237 & $1,148-4,359$ \\
\hline & $\operatorname{Sex}(1)$ & 0,363 & 0,221 & 1,437 & $0,804-2,568$ \\
\hline & Menikah(1) & 0,875 & 0,029 & 2,400 & $1,093-5,268$ \\
\hline & Bekerja(1) & $-0,207$ & 0,564 & 0,813 & $0,403-1,640$ \\
\hline & Constant & $-0,722$ & 0,060 & 0,486 & \\
\hline \multirow{4}{*}{ Step 3} & Kelumur(1) & 0,891 & 0,004 & 2,437 & $1,335-4,450$ \\
\hline & $\operatorname{Sex}(1)$ & 0,419 & 0,134 & 1,521 & $0,879-2,630$ \\
\hline & Menikah(1) & 0,889 & 0,027 & 2,433 & $1,108-5,342$ \\
\hline & Constant & $-0,867$ & 0,003 & 0,420 & \\
\hline \multirow{3}{*}{ Step 4} & Kelumur(1) & 0,957 & 0,002 & 2,604 & $1,437-4,721$ \\
\hline & Menikah(1) & 1,083 & 0,004 & 2,953 & $1,401-6,228$ \\
\hline & Constant & $-0,713$ & 0,009 & 0,490 & \\
\hline
\end{tabular}

5. Nilai -2 Log likelihood $=326,823$ menunjukkan model yang diperoleh merupakan model terbaik dalam memprediksi sikap stigma dan diskriminasi terhadap ODHA. Sehingga hasil persamaannya adalah sebagai berikut:

$$
\begin{aligned}
& g(\mathrm{x})=\ln \left[\frac{\pi(x)}{1-\pi}\right] \\
& g(\mathrm{x}) \\
& =\frac{1}{1+e x^{-(-0,713+0,957(\mathrm{x} 1)(1)+1,083(\mathrm{x} 3)(1)}} \\
& \text { Setelah dilakukan analisis } \\
& \text { multivariabel, faktor yang signifikan } \\
& \text { menjad prediktor sikap stigma dan }
\end{aligned}
$$


demikian, upaya meningkatkan pengetahuan komprehensif tetap harus dilakukan. Diseminasi informasi tentang HIV dan AIDS yang benar dan akurat mutlak diperlukan karena sangat penting tidak hanya untuk meningkatkan pengetahuan tetapi juga untuk mempercepat penerimaan terhadap ODHA sehingga sikap stigma dan diskriminasi terhadap ODHA bisa berkurang.

Akhirnya, hasil penelitian ini juga syarat dengan keterbatasan. Diantara keterbatasan tersebut adalah instrumen dan metode pengukuran pengetahuan tentang HIV dan AIDS serta pengukuran sikap stigma dan diskriminasi terhadap ODHA. Hasil dalam penelitian ini sangat mungkin dipengaruhi oleh faktor endogen seperti disain studi cross sectional sehingga kurang kuat dalam mengidentifikasi hubungan sebab akibat. Dengan demikian, keterbatasan penelitian ini hendaklah menjadi perhatian bagi peneliti selanjutnya agar lebih memahami situasi dan konteks stigma dan diskriminasi terhadap ODHA sehingga diperoleh rumusan strategi yang tepat dalam upaya pengurangan stigma dan diskriminasi terhadap ODHA di Kabupaten Jember.

\section{SIMPULAN DAN SARAN}

Berdasarkan hasil penelitian ini dapat dirumuskan beberapa kesimpulan berikut (1) tingkat penerimaan terhadap ODHA di Kabupaten Jember masih bersedia membeli makanan jika mengetahui penjualnya $\mathrm{HIV}^{+}$. Lima puluh persen lebih mereka tidak setuju jika guru perempuan yang $\mathrm{HIV}^{+}$tetap mengajar meskipun tidak sakit. Demikian juga terhadap anak yang HIV+ belum bisa diterima sekolah bersama anak yang HIV, (2) Distribusi sikap stigma dan diskriminasi terhadap ODHA secara signifikan berbeda menurut usia, jenis kelamin, tingkat pendidikan, status pernikahan dan status pekerjaan. Adapun tingkat pengetahuan tentang HIV dan AIDS serta tempat tinggal di pedesaan atau perkotaan tidak berbeda secara signifikan dan (3) faktor yang memenuhi menjadi predictor sikap stigma dan diskriminasi terhadap ODHA adalah usia dan jenis kelamin. Usia lebih muda (15-19 tahun) serta berjenis kelamin perempuan mempunyai kemungkinan lebih besar bersikap menstigma dan mendiskriminasi terhadap ODHA.

Dengan demikian, untuk mengurangi sigma dan diskriminasi terhadap ODHA di Kabupaten Jember perlu upaya peningkatkan pengetahuan komprehensif tetap harus dilakukan melalui diseminasi informasi tentang HIV dan AIDS yang benar dan akurat. Hal ini mutlak diperlukan karena sangat penting tidak hanya untuk meningkatkan pengetahuan tetapi juga untuk mempercepat penerimaan terhadap ODHA sehingga sikap stigma dan diskriminasi terhadap ODHA bisa berkurang.

\section{DAFTAR RUJUKAN}

1] UNAIDS. AIDS Epidemic Update [Internet]. Geneva; 2008. Available from:

http://data.unaids.org/pub/EPIsli 
des/2007/2007_epiupdate_en.pdf.

2] Komisi Penanggulangan AIDS Kabupaten Jember. Kompi Ni'mal Baroya : Prediktor Sikap Stigma dan .....

Regression: A Self-Learning Text. Second Edi. Verlag New York: HIV dan IDS Triwulan II KPA Kabupaten Jember Tahun 2017. Jember; 2017.

3] Greeff M, Phetlhu R, Makoae LN. Disclosure of HIV status: experience and perceptions of persons living with HIV/AIDS and nurses involved in their care in Africa. Qual Health Res. 2008;18(3):311-24.

4] Rankin W, Brennan S, Schell E, Laviwa J, Rankin SH. The Stigma of Being HIV-positive in Africa. PloS Med. 2005;2(8):e.247.

5] Gerbert B, Sumser J, Maguire TT. The impact of who you know and where you live on opinions about AIDS and health care. Soc Sci Med. 1991;32(6):677-81.

6] Busza J. Challenging HIv-related stigma and discriminations in Southeast Asia:past successes and future priorities (review). New York: Population Council Horizon; 1999.

7] Letamo G. Prevalence of, and Factors Associated with, HIV/AIDS-related Stigma and Discriminatory Attitudes in Botswana. J Heal Popul Nutr. 2003;21(4):347-57.

8] Nyblade L, Field ML. Women, communities, and the prevention of mother-to-child transmission of HIV: issues and findings from community research in Botswana and Zambia. [Internet]. Available from: http://www.icrw.org

9] Kleinbanum DG, Klein M. Logistic 10] Chiao C, Mishra V, Sambisa W. Individual-and Community-level Determinants of Social Acceptance of People Living with HIV in Kenya: Results from a National PopulationBased Survey. Maryland USA; 2008.

11] Amuyunzu-Nyamongo $M$, Okeng'o L, Wagura A, Mwenza E. Putting on a Brave Face: The Experiences of Women Living With HIV and AIDS in Informal Settlements of Nairobi, Kenya. AIDS Care. 2007;19((supplement 1)):S25-34.

12] UNAIDS. Report on the Global AIDS Epidemic: 4th Global Report. Geneva; 2004.

13] Muyinda H, Seeley J, Pickering $H$, Barton T. Social Aspects of AIDSrelated stigma in rural Uganda. Heal Place. 1997;3(3):143-7.

14] Herek GM, Capitano JP, Widaman KF. HIV-related stigma and knowledge in the United States: Prevalence Trends, 1991-1999. Am J Public Heal. 2002;92(3):371-7.

15] Ezedinachi, E. N. E., M. W. Ross, M. Meremiku, E. J. Essienb. C. B. Edema. E. Ekurea and OI. The Impact of an entervention to change workers HIV/AIDS attitudes and knowledge in Nigeria: A controlled trial. Public Health. 2002;16(2):106-12.

16] VanLadingham $M, \quad I m-e m ~ W$, Saengtienchai C. Community reactions to person with HIV/AIDS and their parents in Thailand. Michigan; 2005. 